\section{PENGATURAN HUKUM MENGENAI DOKUMEN PERJALANAN MENURUT UNDANG-UNDANG NOMOR 6 TAHUN 2011 TENTANG KEIMIGRASIAN ${ }^{1}$ \\ Oleh: Sinji Laluraa ${ }^{2}$ \\ Tommy F. Sumakul ${ }^{3}$ \\ Marthim N. Tooy ${ }^{4}$}

\begin{abstract}
ABSTRAK
\end{abstract}
Penelitian ini dilakukan dengan tujuan untuk mengetahui bagaimana pengaturan hukum mengenai dokumen perjalanan Republik Indonesia dan bagaimana pemberlakuan ketentuan pidana pada orang akibat tidak menggunakaan atau memalsukan dokumen perjalanan Republik Indonesia. Dengan menggunakan metode penelitian yuridis normative, disimpulkan: 1 . Pengaturan hukum mengenai dokumen perjalanan Republik Indonesia sesuai Undang-Undang Nomor 6 Tahun 2011 tentang Keimigrasian, meliputi dokumen perjalanan Republik Indonesia terdiri atas paspor dan surat perjalanan laksana paspor. Paspor terdiri atas paspor diplomatik, paspor dinas dan paspor biasa. Surat perjalanan laksana paspor terdiri atas surat perjalanan laksana paspor untuk warga negara Indonesia dan untuk orang asing serta surat perjalanan lintas batas atau pas lintas batas. Dokumen Perjalanan Republik Indonesia merupakan dokumen Negara yang setiap saat dapat ditarik kembali apabila diperlukan untuk kepentingan negara. Dokumen itu bukanlah surat berharga sehingga dokumen perjalanan Republik Indonesia tidak dapat digunakan untuk hal yang bersifat perdata, antara lain dijadikan jaminan utang. 2. Pemberlakuan ketentuan pidana akibat tidak menggunakan atau memalsukan dokumen perjalanan Republik Indonesia, diantaranya setiap orang asing yang masuk dan/atau berada di wilayah Indonesia yang tidak memiliki dokumen perjalanan dan visa yang sah dan masih berlaku atau menggunakan dokumen perjalanan Republik Indonesia untuk masuk atau keluar wilayah Indonesia, tetapi diketahui atau patut diduga bahwa dokumen perjalanan Republik Indonesia itu palsu atau

\footnotetext{
${ }^{1}$ Artikel Skripsi

${ }^{2}$ Mahasiswa pada Fakultas Hukum Unsrat, NIM. 16071101213

${ }^{3}$ Fakultas Hukum Unsrat, Doktor IImu Hukum

${ }^{4}$ Fakultas Hukum Unsrat, Magister IImu Hukum
}

dipalsukan dipidana dengan pidana penjara paling lama 5 (lima) tahun dan pidana denda paling banyak Rp500.000.000,00 (lima ratus juta rupiah).

Kata kunci: Pengaturan Hukum, Dokumen Perjalanan, Keimigrasian

\section{PENDAHULUAN}

\section{A. Latar Belakang}

Hukum keimigrasian adalah himpunan petunjuk yang mengatur tata tertib orangorang yang berlalu lintas di dalam wilayah Republik Indonesia dan pengawasan terhadap orang-orang asing yang berada di wilayah Indonesia. ${ }^{5}$

Pengaturan keimigrasian yang meliputi lalulintas orang masuk atau ke luar wilayah Indonesia, merupakan hak dan wewenang negara Republik Indonesia serta merupakan salah satu perwujudan dari kedaulatannya sebagai negara hukum. Makna keimigrasian bagi warga negara adalah setiap warga negara berhak melakukan perjalanan masuk dan keluar wilayah Indonesia. ${ }^{6}$

Masuk dan keluar wilayah Indonesia, maka setiap orang yang masuk atau ke luar wilayah Indonesia wajib memiliki surat perjalanan. Setiap orang dapat ke luar wilayah Indonesia, apabila telah mendapat tanda bertolak, yakni tanda tertentu yang diterakan oleh pejabat imigrasi di tempat pemeriksaan imigrasi dalam surat perjalanan setiap orang yang akan masuk ke Indonesia setelah mendapat izin yang diberikan pada visa atau surat perjalanan untuk memasuki wilayah Indonesia yang diberikan oleh pejabat imigrasi di tempat pemeriksaan imigrasi. Setiap orang asing yang masuk ke wilayah Indonesia, wajib memiliki visa. Visa diberikan kepada orang asing yang maksud dan tujuan kedatangannya di Indonesia bermanfaat serta tidak akan menimbulkan gangguan terhadap ketertiban dan keamanan nasional. ${ }^{7}$

Hukum keimigrasian adalah himpunan petunjuk yang mengatur tata tertib orangorang yang berlalu lintas dalam wilayah Indonesia dan pengawasan terhadap orang-

\footnotetext{
${ }^{5}$ Sihar Sihombing, Hukum Imigrasi, Nuansa Aulia. Bandung. 2009. hlm. 4.

${ }^{6}$ Siswanto Sunarso, Ekstradisi \& Bantuan Timbal Balik Dalam Masalah Pidana Instrumen Penegakan Hukum Pidana Internasional, Rineka Cipta, Jakarta. 2009. hlm. 203.

${ }^{7}$ Ibid.
} 
orang asing yang berada diwilayah Indonesia. Hukum keimigrasian termasuk dalam hukum publik yaitu hukum yang mengatur hubungan antara individu dengan negara (pemerintah). ${ }^{8}$

Pengaturan bidang keimigrasian (lalu lintas keluar masuk) suatu negara, berdasarkan hukum internasional merupakan hak dan wewenang suatu negara. ${ }^{9}$

Hukum Internasional memberikan hak dan wewenang kepada semua negara untuk menjalankan yurisdiksi atas orang dan benda serta perbuatan yang terjadi di dalam wilayah negara tersebut. Hal ini juga berarti bahwa setiap negara berhak untuk merumuskan hal ikhwal lalu lintas antar negara baik orang, benda maupun perbuatan yang terjadi di wilayahnya. Pengaturan terhadap lalu lintas antar negara yang menyangkut orang di suatu wilayah negara, termasuk urusan keimigrasian yang berlaku di setiap negara memiliki sifat universal maupun kekhususan masing-masing negara sesuai dengan nilai dan kebutuhan kenegaraannya. ${ }^{10}$

\section{B. rumusan masalah}

1. Bagaimanakah pengaturan hukum mengenai dokumen perjalanan Republik Indonesia?

2. Bagaimanakah pemberlakuan ketentuan pidana pada orang akibat tidak menggunakaan atau memalsukan dokumen perjalanan Republik Indonesia ?

\section{Metode Penelitian}

Penelitian hukum yang dilakukan dengan cara meneliti bahan pustaka atau data sekunder belaka, dapat dinamakan penelitian hukum normatif atau penelitian hukum kepustakaan (di samping adanya penelitian hukum sosiologis atau empiris yang terutama meneliti data primer). ${ }^{11}$ Penelitian hukum

\footnotetext{
${ }^{8}$ Abdullah Sjahriful. Memperkenalkan Hukum Keimigrasian. Ghalia Indonesia. Jakarta. 1993. hlm. 58. ${ }^{9}$ Ramadhan. K.H. dan Abrar Yusra. Lintas Sejarah Imigrasi Indonesia. Direktorat Jenderal Imigrasi Departemen Hukum dan HAM. RI. Jakarta. 2005. hlm. 12.

${ }^{10}$ Wahyudin Ukun, Deportasi Sebagai Instrumen Penegakan Hukum dan Kedaulatan Negara di Bidang Keimigrasian. PT. Adi Kencana Aji. Jakarta. 2004. hlm.31.

${ }^{11}$ Soerjono Soekanto dan Sri Mamudji, Penelitian Hukum Normatif Suatu Tinjauan Singkat, PT Raja Grafindo Persada, Jakarta. 1995, hlm. 13-14.
}

normatif digunakan dalam menyusun penulisan ini. Metode penelitian hukum normatif menggunakan bahan-bahan hukum yang dikumpulkan melalui studi kepustakaan.

\section{PEMBAHASAN}

\section{A. Pengaturan Hukum Mengenai Dokumen Perjalanan Republik Indonesia}

Secara normatif, penyelenggaraan sistem hukum keimigrasian berdasarkan pada UndangUndang RI Nomor 6 Tahun 2011 tentang Imigrasi. Ketentuan Undang-undang Keimigrasian ini menetapkan Selain itu, terdapat beberapa peraturan pelaksana sebagai berikut:

1. Peraturan Pemerintah RI Nomor 30 Tahun 1994 tentang Tata Cara
Pelaksanaan Cegah Tangkal.

2. Peraturan Pemerintah RI Nomor 31 Tahun 1994 tentang Pengawasan Orang Asing dan Tindakan Keimigrasian.

3. Peraturan Pemerintah RI Nomor 32 Tahun 1994 tentag Visa, Izin Masuk dan Izin Keimigrasian.

4. Peraturan Pemerintah RI Nomor 36 Tahun 1994 tentang Surat Perjalanan Republik Indonesia. ${ }^{12}$

Masalah pemalsuan identitas diri pemohon paspor tidak lepas dari perilaku pemohon paspor, serta kelembagaan pemerintahan mulai dari proses pengurusan identitas diri pemohon hingga pada penerbitan paspor. Hal ini karena dalam pengurusan paspor, terdapat peran dari sejumlah kelembagaan pemerintah, yang secara singkat dimulai dari awal porses pengurusan paspor adalah dimulai dari pengajuan permohonan paspor yang disertai dengan kelengkapan dokumen administrasi kependudukan meliputi: Akta Kelahiran, Kartu Tanda Penduduk, dan Kartu Keluarga. Dalam hal persyaratan administratif dinyatakan lengkap, maka petugas keimigrasian melakukan wawancara untuk mengetahui maksud pengurusan paspor. Setelah dilakukan wawancara, dilanjutkan dengan pengambilan foto, sidik jari dan scen kornea mata. Selanjutnya diteruskan dengan proses pencetakan paspor, dan pengambilan paspor. ${ }^{13}$

\footnotetext{
${ }^{12}$ Lisye Ariani Dalla, Karolus Kopong Medan dan Dhey Wego Tadeus, Op.Cit. hlm. 13.

${ }^{13}$ Ibid. hlm. 13-14.
} 
Undang-Undang Nomor 6 Tahun 2011 tentang Keimigrasian, mengatur mengenai Dokumen Perjalanan Republik Indonesia. Pasal 24 ayat:

(1) Dokumen Perjalanan Republik Indonesia terdiri atas:

a. Paspor; dan

b. Surat Perjalanan Laksana Paspor.

(2) Paspor terdiri atas:

a. Paspor diplomatik;

b. Paspor dinas; dan

c. Paspor biasa.

(3) Surat Perjalanan Laksana Paspor terdiri atas:

a. Surat Perjalanan Laksana Paspor untuk warga negara Indonesia;

b. Surat Perjalanan Laksana Paspor untuk Orang Asing; dan

c. Surat perjalanan lintas batas atau pas lintas batas;

(4) Dokumen Perjalanan Republik Indonesiasebagaimana dimaksud pada ayat (1) merupakan dokumen negara.

Penjelasan Pasal 24 ayat (4) Yang dimaksud dengan "dokumen negara" adalah dokumen yang setiap saat dapat ditarik kembali apabila diperlukan untuk kepentingan negara. Dokumen itu bukanlah surat berharga sehingga Dokumen Perjalanan Republik Indonesia tidak dapat digunakan untuk hal yang bersifat perdata, antara lain dijadikan jaminan utang.

\section{B. Pemberlakuan Ketentuan Pidana Pada Orang Akibat Tidak Menggunakaan Atau Memalsukan Dokumen Perjalanan Republik Indonesia}

Terjadinya tindak pidana keimigrasian seperti pembuatan dan pemalsuan surat perjalanan yang merupakan dokumen resmi yang secara sah seharusnya dikeluarkan oleh pejabat yang berwenang dari suatu negara karena memuat identitas pemegangnya dan berlaku untuk melakukan perjalanan antar negara, memerlukan upaya penegakan hukum meliputi pengawasan terhadap orang yang masuk atau ke luar wilayah Negara Republik Indonesia dan pengawasan orang asing di wilayah Negara Republik Indonesia. ${ }^{14}$ Peran serta masyarakat sangat diperlukan untuk mendukung upaya penegakan hukum yang

\footnotetext{
${ }^{14}$ Lisye Ariani Dalla, Karolus Kopong Medan dan Dhey Wego Tadeus, Op.Cit. hlm. 17
}

dapat diwujudkan dengan tindakan memberikan informasi dan/atau melaporkan adanya penyalahgunaan dokumen negara dan dokumen lainnya untuk kepada penegak hukum atau pihak yang berwajib, termasuk keterlibatan aparatur pemerintah yang dengan sengaja membantu penyalahgunaan dokumen negara dan dokumen lainnya yang dapat digolongkan sebagai tindak pidana keimigrasian. ${ }^{15}$

Adanya dokumen-dokumen keimigrasian dapat dibuat, disimpan, dipalsukan dan disalahgunakan untuk kepentingan diri sendiri maupun orang lain, bahkan dapat digunakan untuk mempermudah terjadinya tindak pidana seperti; terorisme, korupsi, perdagangan orang, narkotika dan psikotropika, penyelundupan kayu dan penyelundupan orang dan tindak pidana lainnya. ${ }^{16}$

Sanksi, sanctie, yaitu: akibat hukum bagi pelanggar ketentuan undang undang. Ada sanksi adminsitratif, ada sanksi perdata dan ada sanksi pidana. ${ }^{17}$

Undang-Undang Nomor 6 Tahun 2011 tentang Keimigrasian, Pasal 119 ayat:

(1) Setiap Orang Asing yang masuk dan/atau berada di Wilayah Indonesia yang tidak memiliki Dokumen Perjalanan dan Visa yang sah dan masih berlaku sebagaimana dimaksud dalam Pasal 8 dipidana dengan pidana penjara paling lama 5 (lima) tahun dan pidana denda paling banyak Rp500.000.000,00 (lima ratus juta rupiah).

(2) Setiap Orang Asing yang dengan sengaja menggunakan Dokumen Perjalanan, tetapi diketahui atau patut diduga bahwa Dokumen Perjalanan itu palsu atau dipalsukan dipidana dengan pidana penjara paling lama 5 (lima) tahun dan pidana denda paling banyak Rp500.000.000,00 (lima ratus juta rupiah).

Pasal 120 ayat:

(1) Setiap orang yang melakukan perbuatan yang bertujuan mencari keuntungan, baik secara langsung maupun tidak langsung, untuk diri sendiri atau untuk orang lain dengan membawa seseorang atau

\footnotetext{
${ }^{15}$ Ibid. hlm. 17.

${ }^{16} \mathrm{lbid}$. hlm. 17.

${ }^{17}$ Andi Hamzah. Terminologi Hukum Pidana, (Editor) Tarmizi, Ed. 1. Cet. 1. Sinar Grafika, Jakarta, 2008. hlm. 138.
} 
kelompok orang, baik secara terorganisasi maupun tidak terorganisasi, atau memerintahkan orang lain untuk membawa seseorang atau kelompok orang, baik secara terorganisasi maupun tidak terorganisasi, yang tidak memiliki hak secara sah untuk memasuki Wilayah Indonesia atau keluar dari Wilayah Indonesia dan/atau masuk wilayah negara lain, yang orang tersebut tidak memiliki hak untuk memasuki wilayah tersebut secara sah, baik dengan menggunakan dokumen sah maupun dokumen palsu, atau tanpa menggunakan Dokumen Perjalanan, baik melalui pemeriksaan imigrasi maupun tidak, dipidana karena Penyelundupan Manusia dengan pidana penjara paling singkat 5 (lima) tahun dan paling lama 15 (limabelas) tahun dan pidana denda paling sedikit Rp500.000.000,00 (lima ratus juta rupiah) dan paling banyak Rp1.500.000.000,00 (satu miliar lima ratus juta rupiah).

(2) Percobaan untuk melakukan tindak pidana Penyelundupan Manusia dipidana dengan pidana yang sama sebagaimana dimaksud pada ayat (1).

Pasal 121. Dipidana dengan pidana penjara paling lama 5 (lima) tahun dan pidana denda paling banyak Rp500.000.000,00 (lima ratus juta rupiah):

a. setiap orang yang dengan sengaja membuat palsu atau memalsukan Visa atau Tanda Masuk atau Izin Tinggal dengan maksud untuk digunakan bagi dirinya sendiri atau orang lain untuk masuk atau keluar atau berada di Wilayah Indonesia;

b. setiap Orang Asing yang dengan sengaja menggunakan Visa atau Tanda Masuk atau Izin Tinggal palsu atau yang dipalsukan untuk masuk atau keluar atau berada di Wilayah Indonesia.

Pasal 122. Dipidana dengan pidana penjara paling lama 5 (lima) tahun dan pidana denda paling paling banyak Rp500.000.000,00 (lima ratus juta rupiah):

a. setiap Orang Asing yang dengan sengaja menyalahgunakan atau melakukan kegiatan yang tidak sesuai dengan maksud dan tujuan pemberian Izin Tinggal yang diberikan kepadanya; b. setiap orang yang menyuruh atau memberikan kesempatan kepada Orang Asing menyalahgunakan atau melakukan kegiatan yang tidak sesuai dengan maksud atau tujuan pemberian Izin Tinggal yang diberikan kepadanya.

Pasal 123. Dipidana dengan pidana penjara paling lama 5 (lima) tahun dan pidana denda paling banyak Rp500.000.000,00 (lima ratus juta rupiah):

a. setiap orang yang dengan sengaja memberikan surat atau data palsu atau yang dipalsukan atau keterangan tidak benar dengan maksud untuk memperoleh Visa atau Izin Tinggal bagi dirinya sendiri atau orang lain;

b. setiap Orang Asing yang dengan sengaja menggunakan Visa atau Izin Tinggal sebagaimana dimaksud dalam huruf a untuk masuk dan/atau berada di Wilayah Indonesia.

Izin adalah suatu persetujuan dari penguasa berdasarkan peraturan perundang-undangan dan peraturan pemerintah. Dengan demikian izin pada prinsipnya memuat larangan, persetujuan yang merupakan dasar pengecualian. Pengecualian itu harus diberikan oleh undang-undang untuk menunjukkan legalitas sebagai suatu ciri negara hukum yang demokrasi. ${ }^{18}$

Undang-Undang Nomor 6 Tahun 2011 tentang Keimigrasian. Pasal 126. Setiap orang yang dengan sengaja:

a. menggunakan Dokumen Perjalanan Republik Indonesia untuk masuk atau keluar Wilayah Indonesia, tetapi diketahui atau patut diduga bahwa Dokumen Perjalanan Republik Indonesia itu palsu atau dipalsukan dipidana dengan pidana penjara paling lama 5 (lima) tahun dan pidana denda paling banyak Rp500.000.000,00 (lima ratus juta rupiah);

b. menggunakan Dokumen Perjalanan Republik Indonesia orang lain atau yang sudah dicabut atau yang dinyatakan batal untuk masuk atau keluar Wilayah Indonesia atau menyerahkan kepada orang lain Dokumen Perjalanan Republik Indonesia yang diberikan kepadanya atau milik orang lain dengan maksud digunakan secara tanpa hak

\footnotetext{
${ }^{18} \mathrm{H}$. Juniarso Ridwan dan Achmad Sodik Sudrajat, Hukum Adminsitrasi Negara dan Kebijakan Pelayanan Publik, Cetakan I. Nuansa. Bandung. 2010, hlm. 92.
} 
dipidana dengan pidana penjara paling lama 5 (lima) tahun dan pidana denda paling banyak Rp500.000.000,00 (lima ratus juta rupiah);

c. memberikan data yang tidak sah atau keterangan yang tidak benar untuk memperoleh Dokumen Perjalanan Republik Indonesia bagi dirinya sendiri atau orang lain dipidana dengan pidana penjara paling lama 5 (lima) tahun dan pidana denda paling banyak Rp500.000.000,00 (lima ratus juta rupiah);

d. memiliki atau menggunakan secara melawan hukum 2 (dua) atau lebih Dokumen Perjalanan Republik Indonesia yang sejenis dan semuanya masih berlaku dipidana dengan pidana penjara paling lama 5 (lima) tahun dan pidana denda paling banyak Rp500.000.000,00 (lima ratus juta rupiah);

e. memalsukan Dokumen Perjalanan Republik Indonesia atau membuat Dokumen Perjalanan Republik Indonesia palsu dengan maksud untuk digunakan bagi dirinya sendiri atau orang lain dipidana dengan pidana penjara paling lama 5 (lima) tahun dan pidana denda paling banyak Rp500.000.000,00 (lima ratus juta rupiah).

Pasal 127. Setiap orang yang dengan sengaja dan melawan hukum menyimpan Dokumen Perjalanan Republik Indonesia palsu atau dipalsukan dengan maksud untuk digunakan bagi dirinya sendiri atau orang lain dipidana dengan pidana penjara paling lama 5 (lima) tahun dan pidana denda paling banyak Rp500.000.000,00 (lima ratus juta rupiah).

Pasal 128. Dipidana dengan pidana penjara paling lama 5 (lima) tahun dan pidana denda paling banyak Rp500.000.000,00 (lima ratus juta rupiah):

a. setiap orang yang dengan sengaja dan melawan hukum mencetak, mempunyai, menyimpan, atau memperdagangkan blanko Dokumen Perjalanan Republik Indonesia atau blanko Dokumen Keimigrasian lainnya;

b. setiap orang yang dengan sengaja dan melawan hukum membuat, mempunyai, menyimpan, atau memperdagangkan cap atau alat lain yang digunakan untuk mengesahkan Dokumen Perjalanan Republik Indonesia atau Dokumen Keimigrasian lainnya.
Pasal 129. Setiap orang yang dengan sengaja dan melawan hukum untuk kepentingan diri sendiri atau orang lain merusak, mengubah, menambah, mengurangi, atau menghilangkan, baik sebagian maupun seluruhnya, keterangan atau cap yang terdapat dalam Dokumen Perjalanan Republik Indonesia atau Dokumen Keimigrasian lainnya dipidana dengan pidana penjara paling lama 5 (lima) tahun dan pidana denda paling banyak Rp500.000.000,00 (lima ratus juta rupiah).

Pasal 130. Setiap orang yang dengan sengaja dan melawan hukum menguasai Dokumen Perjalanan atau Dokumen Keimigrasian lainnya milik orang lain dipidana dengan pidana penjara paling lama 2 (dua) tahun dan/atau pidana denda paling banyak Rp200.000.000,00 (dua ratus juta rupiah).

Pasal 131.Setiap orang yang dengan sengaja tanpa hak dan melawan hukum memiliki, menyimpan, merusak, menghilangkan, mengubah, menggandakan, menggunakan dan atau mengakses data Keimigrasian, baik secara manual maupun elektronik, untuk kepentingan diri sendiri atau orang lain dipidana dengan pidana penjara paling lama 5 (lima) tahun dan pidana denda paling banyak Rp500.000.000,00 (lima ratus juta rupiah). Pasal 132. Pejabat Imigrasi atau pejabat lain yang ditunjuk yang dengan sengaja dan melawan hukum memberikan Dokumen Perjalanan Republik Indonesia dan/atau memberikan atau memperpanjang Dokumen Keimigrasian kepada seseorang yang diketahuinya tidak berhak dipidana dengan pidana penjara paling lama 7 (tujuh) tahun. Pasal 133.Pejabat Imigrasi atau pejabat lain:

a. membiarkan seseorang melakukan tindak pidana Keimigrasian sebagaimana dimaksud Pasal 118, Pasal 119, Pasal 120, Pasal 121, Pasal 122, Pasal 123, Pasal 126, Pasal 127, Pasal 128, Pasal 129, Pasal 131, Pasal132, Pasal 133 huruf $b$, Pasal 134 huruf $b$, dan Pasal 135 yang patut diketahui olehnya dipidana dengan pidana penjara paling lama 5 (lima) tahun;

b. dengan sengaja membocorkan data Keimigrasian yang bersifat rahasia kepada pihak yang tidak berhak sebagaimana dimaksud dalam Pasal 67 ayat (2) dan Pasal 68 ayat (2) dipidana dengan pidana penjara paling lama 5 (lima) tahun; 
c. dengan sengaja tidak menjalankan prosedur operasi standar yang berlaku dalam proses pemeriksaan pemberangkatan atau kedatangan di Tempat Pemeriksaan Imigrasi yang mengakibatkan masuknya Orang Asing ke Wilayah Indonesia sebagaimana dimaksud dalam Pasal 13 ayat (1) atau keluarnya orang dari Wilayah Indonesia sebagaimana dimaksud dalam Pasal 16 ayat (1) dipidana dengan pidana penjara paling lama 2 (dua) tahun;

d. dengan sengaja dan melawan hukum tidak menjalankan prosedur operasi standar penjagaan Deteni di Rumah Detensi Imigrasi atau Ruang Detensi Imigrasi yang mengakibatkan Deteni melarikan diri dipidana dengan pidana penjara paling lama 2 (dua) tahun;

e. dengan sengaja dan melawan hukum tidak memasukkan data ke dalam Sistem Informasi Manajemen Keimigrasian sebagaimana dimaksud dalam Pasal 70 dipidana dengan pidana kurungan paling lama 6 (enam) bulan.

Perbuatan pidana semata menunjuk pada perbuatan baik secara aktif maupun secara pasif, sedangkan apakah pelaku ketika melakukan perbuatan pidana patut dicela atau memiliki kesalahan, bukan merupakan wilayah perbuatan pidana, tetapi sudah masuk pada pertanggungjawaban pidana. ${ }^{19}$

Perbuatan pidana adalah perbuatan yang dilarang oleh suatu aturan hukum, larangan mana disertai ancaman (sanksi) yang berupa pidana tertentu, bagi barang siapa yang melanggar larangan tersebut. ${ }^{20}$

Dapat juga dikatakan bahwa perbuatan pidana adalah perbuatan oleh suatu aturan hukum dilarang dan diancam pidana, asal saja dalam pada itu diingat bahwa larangan ditujukan kepada perbuatan (yaitu suatu keadaan atau kejadian yang ditimbulkan oleh kelakuan orang), sedangkan ancaman pidanya ditujukan kepada orang yang menimbulkan kejadian itu. ${ }^{21}$

Kata delik berasal dari bahasa latin, yakni delictum. Dalam bahasa Jerman disebut delict,

\footnotetext{
${ }^{19}$ Ali Mahrus, Dasar-Dasar Hukum Pidana, Cetakan Pertama, Sinar Grafika, Jakarta, 2011. hlm. 97

${ }^{20}$ Moeljatno, Asas-Asas Hukum Pidana, Edisi Revisi, PT. Rineka Cipta, Jakarta, 2008, hlm. 59 ${ }^{21}$ Ibid.
}

dalam bahasa Perancis disebut delit dan dalam bahasa Belanda disebut delict. Dalam Kamus Besar Bahasa Indonesia, arti delik diberi batasan sebagai berikut: "perbuatan yang dapat dikenakan hukuman karena merupakan pelanggaran terhadap undang-undang tindak pidana". ${ }^{22}$

Penegakan hukum (pidana) meliputi tiga tahap. Tahap pertama, tahap formulasi yakni tahap penegakan hukum in abtracto oleh badan pembuat undang-undang (tahap legislatif). Tahap kedua, tahap aplikasi yakni tahap penerapan hukum pidana oleh para aparat penegak hukum mulai dari kepolisian, kejaksaan sampai pengadilan (tahap yudikatif). Tahap ketiga, tahap eksekusi, yakni tahap pelaksanaan hukum pidana secara konkret oleh aparat-aparat pelaksana pidana (tahap eksekutif atau administrasi). ${ }^{23}$ Sebagai suatu sistem masyarakat, sistem peradilan pidana bertujuan untuk: (a) mencegah masyarakat menjadi korban kejahatan; (b) menyelesaikan kasus kejahatan yang terjadi sehingga masyarakat puas, bahwa keadilan telah ditegakkan dan yang bersalah di pidana; (c) mengusahakan agar mereka yang pernah melakukan kejahatan tidak mengulangi lagi kejahatannya. ${ }^{24}$

Bila mengacu kepada tujuan sistem peradilan pidana itu, bisa diartikan sebagai usaha mencegah dan menanggulangi kejahatan. Di sini pelaku dijatuhi pidana dan direhabilitasi serta dilindunginya korban dan masyarakat. Adapun subsistem yang bekerja sama di dalam sistem peradilan pidana adalah: Kepolisian, Kejaksaan, Pengadilan dan Lembaga Pemasyarakatan. Dari keempat instansi ini yang sangat berkaitan dengan proses dijatuhkannya pidana penjara adalah kepolisian sebagai penyidik, jaksa penuntut umum dan hakim. Ketiga sub sistem ini selalu identik dengan penegak hukum dalam arti bahwa ketiga instansi ini yang menentukan seseorang itu dijatuhi hukuman atau tidak, utamanya hakim. $^{25}$

\footnotetext{
${ }^{22}$ Leden Marpaung, Asas-Teori-Praktik Hukum Pidana, Sinar Grafika. 2005, Jakarta, hlm. 7.

${ }^{23}$ Aziz Syamsuddin, Tindak Pidana Khusus, Cetakan Pertama, Sinar Grafika, Jakarta, 2011, hlm. 2-3. ${ }^{24}$ Petrus Irwan Panjaitan \& Chairijah, Pidana Penjara Dalam Perspektif Penegak Hukum Masyarakat dan Narapidana, CV. Indhili. Co, Jakarta, Juni 2009, hlm. 56. ${ }^{25}$ Ibid.
} 
Norma hukum adalah peraturan hidup yang bersifat memaksa dan mempunyai sanksi yang tegas. Peraturan yang timbul dari norma hukum dibuat oleh penguasa negara. Isinya mengikat setiap orang dan pelaksanaannya dapat dipertahankan dengan segala paksaan oleh alat-alat negara. Keistimewaan norma hukum itu justeru terletak pada sifatnya yang memaksa dengan sanksinya yang berupa ancaman hukuman. Alat kekuasaan negara yang berusaha agar peraturan hukum ditaati dan dilaksanakan. Setiap norma paling tidak mempunyai beberapa unsur, yaitu: ${ }^{26}$

1. Sumber, yaitu dari mana asal norma itu;

2. Sifat, yaitu syarat-syarat kapan norma itu berlaku;

3. Tujuan, yaitu untuk apakah norma itu dibuat;

4. Sanksi, yaitu reaksi (alat pemaksa) apakah yang akan dikenakan kepada orang yang melanggar atau tidak mematuhi norma itu.

Menurut Kansil dalam pergaulan masyarakat terdapat aneka macam hubungan di antara anggota masyarakat, yakni hubungan yang ditimbulkan oleh kepentingan-kepentingan anggota masyarakat itu, karena beraneka ragamnya hubungan itu, para anggota masyarakat memerlukan aturan-aturan yang dapat menjamin keseimbangan agar dalam hubungan-hubungan itu tidak terjadi kekacauan di dalam masyarakat. ${ }^{27}$

Peraturan-peraturan hukum yang bersifat mengatur dan memaksa anggota masyarakat untuk patuh dalam menaatinya akan menciptakan keseimbangan dalam setiap hubungan di dalam masyarakat. Setiap pelanggaran atas peraturan yang ada akan dikenakan sanksi atau hukuman sebagai reaksi terhadap perbuatan yang melanggar peraturan. ${ }^{28}$

Untuk menjaga agar peraturan-peraturan itu dapat berlangsung terus-menerus dan diterima oleh seluruh anggota masyarakat, aturan hukum yang ada harus sesuai dan tidak boleh bertentangan dengan rasa keadilan masyarakat. Dengan demikian, hukum bertujuan untuk menjamin adanya kepastian

\footnotetext{
${ }^{26}$ Yulies Tiena Masriani. Pengantar Hukum Indonesia, Cetakan Kelima, Sinar Grafika, Jakarta. 2009. hlm. 5-6.

${ }^{27}$ Arus Akbar Silondae dan Wirawan B. Ilyas. Pokok-Pokok Hukum Bisnis. Salemba Empat. Jakarta. 2011. hal. 3.

${ }^{28}$ Ibid. hal. 3
}

hukum dalam masyarakat dan harus bersendikan pada keadilan yaitu rasa keadilan masyarakat. ${ }^{29}$

Hukum sebagai norma mempunyai ciri kekhususan, yaitu hendak melindungi, mengatur dan memberikan keseimbangan dalam menjaga kepentingan umum. Pelanggaran ketentuan hukum dalam arti merugikan, melalaikan atau mengganggu keseimbangan kepentingan umum dapat menimbulkan reaksi dari masyarakat. Reaksi yang diberikan berupa pengembalian ketidakseimbangan yang dilakukan dengan mengambil tindakan terhadap pelanggarnya. Pengembalian ketidakseimbangan bagi suatu kelompok sosial yang teratur dilakukan oleh petugas yang berwenang dengan memberikan hukuman. ${ }^{30}$

\section{PENUTUP}

\section{A. Kesimpulan}

1. Pengaturan hukum mengenai dokumen perjalanan Republik Indonesia sesuai Undang-Undang Nomor 6 Tahun 2011 tentang Keimigrasian, meliputi dokumen perjalanan Republik Indonesia terdiri atas paspor dan surat perjalanan laksana paspor. Paspor terdiri atas paspor diplomatik, paspor dinas dan paspor biasa. Surat perjalanan laksana paspor terdiri atas surat perjalanan laksana paspor untuk warga negara Indonesia dan untuk orang asing serta surat perjalanan lintas batas atau pas lintas batas. Dokumen Perjalanan Republik Indonesia merupakan dokumen Negara yang setiap saat dapat ditarik kembali apabila diperlukan untuk kepentingan negara. Dokumen itu bukanlah surat berharga sehingga dokumen perjalanan Republik Indonesia tidak dapat digunakan untuk hal yang bersifat perdata, antara lain dijadikan jaminan utang.

2. Pemberlakuan ketentuan pidana akibat tidak menggunakan atau memalsukan dokumen perjalanan Republik Indonesia, diantaranya setiap orang asing yang masuk dan/atau berada di wilayah

\footnotetext{
${ }^{29}$ Ibid.

${ }^{30}$ Abdoel Djamali. Pengantar Hukum Indonesia. Rajawali Pers. PT. Raja Grafindo Persada. Jakarta. 2009. hlm. 3.
} 
Indonesia yang tidak memiliki dokumen perjalanan dan visa yang sah dan masih berlaku atau menggunakan dokumen perjalanan Republik Indonesia untuk masuk atau keluar wilayah Indonesia, tetapi diketahui atau patut diduga bahwa dokumen perjalanan Republik Indonesia itu palsu atau dipalsukan dipidana dengan pidana penjara paling lama 5 (lima) tahun dan pidana denda paling banyak Rp500.000.000,00 (lima ratus juta rupiah).

\section{B. Saran}

1. Pengaturan hukum mengenai dokumen perjalanan Republik Indonesia memerlukan dukungan pengawasan keimigrasian untuk melakukan pengawasan terhadap warga negara Indonesia yang memohon dokumen perjalanan, keluar atau masuk Wilayah Indonesia, dan yang berada di luar Wilayah Indonesia; dan pengawasan terhadap lalu lintas Orang Asing yang masuk atau keluar Wilayah Indonesia serta pengawasan terhadap keberadaan dan kegiatan Orang Asing di Wilayah Indonesia.

2. Pemberlakuan ketentuan pidana akibat tidak menggunakan atau memalsukan dokumen perjalanan Republik Indonesia memerlukan dukungan Penyidik Pegawai Negeri Sipil Keimigrasian (PPNS) Keimigrasian menyerahkan tersangka dan alat bukti kepada penuntut umum dengan disertai catatan mengenai tindak pidana Keimigrasian yang disangkakan kepada tersangka.PPNS Keimigrasian dapat melaksanakan kerja sama dalam penyelidikan dan penyidikan tindak pidana Keimigrasian dengan lembaga penegak hukum dalam negeri dan Negara lain sesuai dengan ketentuan peraturan perundang-undangan atau berdasarkan perjanjian internasional yang telah diakui oleh Pemerintah Republik Indonesia.

\section{DAFTAR PUSTAKA}

Adolf Huala, Aspek-Aspek Negara Dalam Hukum Internasional, Keni Media Bandung. 2011.
Atmasasmita Romli, Pengantar Hukum Pidana Internasional, Refika Aditama, Cetakan, Pertama. Bandung. 2000.

Djamali Abdoel. Pengantar Hukum Indonesia. Rajawali Pers. PT. Raja Grafindo Persada. Jakarta. 2009.

Hamzah Andi. Terminologi Hukum Pidana, (Editor) Tarmizi, Ed. 1. Cet. 1. Sinar Grafika, Jakarta, 2008.

Hariri Muhwan Wawan. Pengantar IImu Hukum, Cet. 1. CV. Pustaka Setia Bandung. 2012.

H, Lucky Valentinus Adam Idris dan Masjaya. Implementasi Pelayanan Dokumen Perjalanan Republik Indonesia (Paspor) Di Kantor Imigrasi Kelas I Kota Samarinda. Jurnal Administrative Reform, Vol.3 No.1,Januari-Maret 2015.

Husni Lalu, Pengantar Hukum Ketenagakerjaan Indonesia, Edisi Revisi, PT. RajaGrafindo, Jakarta, 2008.

K.H. Ramadhan. dan Abrar Yusra. Lintas Sejarah Imigrasi Indonesia. Direktorat Jenderal Imigrasi Departemen Hukum dan HAM. RI. Jakarta. 2005.

K.H. Ramadhan. dan Abrar Yusra. Lintas Sejarah Imigrasi Indonesia. Direktorat Jenderal Imigrasi Departemen Hukum dan HAM. RI. Jakarta. 2005.

Mahmud Marzuki Peter, Penelitian Hukum, Edisi Pertama Cetakan ke-2, Kencana Prenada Media Group, Jakarta, 2006.

Mahrus Ali, Dasar-Dasar Hukum Pidana, Cetakan Pertama, Sinar Grafika, Jakarta, 2011.

Marpaung Leden, Asas-Teori-Praktik Hukum Pidana, Sinar Grafika. Jakarta. 2005.

Masriani Tiena Yulies. Pengantar Hukum Indonesia, Cetakan Kelima, Sinar Grafika, Jakarta. 2009.

Moeljatno, Asas-Asas Hukum Pidana, Edisi Revisi, PT. Rineka Cipta, Jakarta, 2008.

Panjaitan Irwan Petrus \& Chairijah, Pidana Penjara Dalam Perspektif Penegak Hukum Masyarakat dan Narapidana, CV. Indhili. Co, Jakarta, Juni 2009.

Parthiana Wayan I., Hukum Pidana Internasional, Cet. I. Yrama Widya, Bandung, 2006.

Ridwan Juniarso $H$. dan Achmad Sodik Sudrajat, Hukum Adminsitrasi Negara 
dan Kebijakan Pelayanan Publik, Cetakan I. Nuansa. Bandung. 2010.

Rudy May T., Hukum Internasional 1. Cetakan Ketiga, PT. Refika Aditama, Bandung. 2010.

Santoso Iman M., Perspektif Imigrasi, Perum Percetakan Negara Republik Indonesia. Jakarta. 2007.

Silondae Akbar Arus dan Wirawan B. Ilyas. Pokok-Pokok Hukum Bisnis. Salemba Empat. Jakarta. 2011.

Soekanto Soerjono dan Sri Mamudji, Penelitian Hukum Normatif Suatu Tinjauan Singkat, PT Raja Grafindo Persada, Jakarta. 1995.

Soekanto Soerjono, Pengantar Penelitian Hukum, UI Press, Jakarta, 2005.

Sihombing Sihar. Hukum Imigrasi. Nuansa Aulia. Bandung. 2006.

Sihombing Sihar, Hukum Imigrasi, Nuansa Aulia. Bandung. 2009.

Siswosoediro S. Henry. Buku Pintar Pengurusan Perizinan \& Dokumen. Visimedia. Jakarta. 2008.

Sjahriful Abdullah. Memperkenalkan Hukum Keimigrasian. Ghalia Indonesia. Jakarta. 1993.

Sunarso Siswanto, Ekstradisi \& Bantuan Timbal Balik Dalam Masalah Pidana Instrumen Penegakan Hukum Pidana Internasional, Rineka Cipta, Jakarta. 2009.

Syamsuddin Aziz, Tindak Pidana Khusus, Cetakan Pertama, Sinar Grafika, Jakarta, 2011.

Ukun Wahyudin, Deportasi Sebagai Instrumen Penegakan Hukum dan Kedaulatan Negara di Bidang Keimigrasian. PT. Adi Kencana Aji. Jakarta. 2004.

Usman, Aspek-Aspek Hukum Perbankan di Indonesia. Penerbit Gramedia Pustaka Utama. Jakarta. 2001.

Jurnal

Arif Andy Muhammad. Efektivitas Pelayanan Publik Dalam Penerapan Sistem Penerbitan Surat Perjalanan Republik Indonesia (Spri) Di Kantor Imigrasi Kelas I Polonia Medan Edisi IV No. 4 Juli-Desember 2018 I Jurnal Publik Reform UNDHAR Medan.
Dalla Ariani Lisye, Karolus Kopong Medan dan Dhey Wego Tadeus, Tanggungjawab Keimigrasian Terhadap Pemalsuan Identitas Pemohon Paspor (Kasus Kantor Imigrasi Kelas I Kupang) Jurnal Proyuris Vol.1 No.1 Juli 2019.

Johan Eva. Kebijakan Indonesia Terhadap Imigran Ilegal Dan Hubungannya Dengan Kedaulatan Negara. Yuridika:Volume 28 No 1, Januari-April 2013.

Johan Eva. Kebijakan Indonesia Terhadap Imigran Ilegal Dan Hubungannya Dengan Kedaulatan Negara. Yuridika:Volume 28 No 1, Januari-April 2013. hlm. 5. (Lihat International Organization for Migrations, Petunjuk Penanganan Tindak Pidana Penyelundupan Manusia (Pencegatan, Penuntutan dan Koordinasi di Indonesia) (IOM, 2012) 2-3.

Waruwu Henrikus, Beby Masitho, Efektivitas Pelayanan Paspor Pada Kantor Imigrasi Kelas I Khusus Medan. Jurnal Ilmu Administrasi Publik 4 (1) (2016): 43-51.

\section{Peraturan Perundang-Undangan}

Undang-Undang Nomor 6 Tahun 2011 Tentang Keimigrasian.

Peraturan Pemerintah Republik Indonesia Nomor 31 Tahun 2013 Tentang Peraturan Pelaksanaan Undang-Undang Nomor 6 Tahun 2011 Tentang Keimigrasian.

\section{Internet}

https://www.bisnis.com/user/604/newswire.La nggar UU Imigrasi, Tiga Warga China Dipulangkan Dari Palu. Diakses 1/25/2020 7:31 Wita. 